\title{
Juveniles' Right to Counsel during Police Interrogations: An Interdisciplinary Analysis of a Youth-Specific Approach, with a Particular Focus on the Netherlands
}

\author{
Ton Liefaard \& Yannick van den Brink*
}

\section{Abstract}

The right to counsel of juveniles at the stage of police interrogations has gained significant attention since the Salduz ruling of the European Court on Human Rights in 2008. The legislative and policy developments that have taken place since then and that are still ongoing - both on a regional (European) and domestic (Dutch) level - reveal a shared belief that juvenile suspects must be awarded special protection in this phase of the criminal justice proceedings. This calls for a youth-specific approach as fundamentally different from the common approach for adults. At the same time, there seems to be ambivalence concerning the justification and concrete implications of such a youth-specific approach. This article aims to clarify the underlying rationale and significance of a youth specific approach to the right to counsel at the stage of police interrogations on the basis of an interdisciplinary analysis of European Court on Human Rights case law, international children's rights standards and relevant developmental psychological insights. In addition, this article aims to position this right of juveniles in conflict with the law in the particular context of the Dutch juvenile justice system and provide concrete recommendations to the Dutch legislator.

Keywords: legal representation, counsel, juvenile justice, police interrogations, children's rights

\section{Introduction}

Influenced by recent developments in the case law of the European Court of Human Rights (ECtHR), the Dutch Supreme Court ruled, on the 30th of June 2009, that all arrested suspects have the right to consult a lawyer prior to the first police interrogation and that juvenile suspects have the additional right of having a lawyer or other representative present during the police

Prof. Dr. T. Liefaard is Professor of Children's Rights (UNICEF Chair) at Leiden Law School, Department of Child Law; t.liefaard@law.leiden univ.nl. Y.N. van den Brink, LL.M, MA, is PhD researcher at Leiden Law School, Department of Child Law; y.n.van.den.brink@law.leidenuniv.nl. interrogation. ${ }^{1}$ The Dutch Supreme Court, thus, clarified that juveniles are entitled to a higher level of protection at the stage of police interrogations. This 'youthspecific' ruling has had a significant impact on the Dutch practice of legal representation of juvenile suspects in the earliest stage of criminal investigation. In 2010, a youth-specific policy approach to the right to counsel was adopted in the policy directive 'Aanmijzing rechtsbijstand politieverhoor', commissioned by the Board of Procurators General, ${ }^{2}$ followed by a 2011 Draft Bill on legal representation in the context of police interrogations. ${ }^{3}$ In February 2014, the Draft Bill was divided into two separate Draft Bills. ${ }^{4}$

Both in the Netherlands and internationally, there seems to be consensus that juvenile suspects must be awarded special protection at the stage of police interrogations, which calls for a youth-specific approach fundamentally different from the common approach for adults. At the same time, there is ambivalence concerning the justifications underlying a youth-specific approach and the concrete implications of such an approach. With regard to the latter, it is interesting to note that the Dutch Supreme Court defines the presence of a lawyer during police interrogations as the key element of a youth-specific approach, while the recently adopted European Union (EU) Directive on the right of access to a lawyer in criminal proceedings 5 indicates that the right to legal counsel at the stage of police interrogations has more or less similar implications for accused juveniles and adults, even though the 'particular needs of vulnerable suspects' (i.e. among others, minors) have

1. Dutch Supreme Court, 30 June 2009, ECLI:NL:HR:2009:BH3081

2. 'Aanwijzing Rechtsbijstand Politieverhoor', Dutch Bulletin of Acts and Decrees, at 4003 (2010).

3. Draft Bill of 15 April 2011. Retrieved from: <www.rijksoverheid.nl/ documenten-en-publicaties/regelingen/2011/04/18/wetsvoorstrechtsbijstand-en-politieverhoor.html>

4. Draft Bills of 13 February 2014. Retrieved from: <www.rijksoverheid.nl/ nieuws/2014/02/13/recht-op-bijstand-van-raadsman-tijdenspolitieverhoor.html>.

5. Directive 2013/48/EU of the European Parliament and of the Council of 22 October 2013, OJ 2013 L 294. See in particular Art. 13. 
to be taken into account by Member States. ${ }^{6}$ In addition, the European Union is currently preparing a youth-specific EU Directive, which is much more concrete in terms of awarding juvenile suspects special protection and is strongly influenced by the children's rights-oriented Guidelines for Child Friendly Justice of the Council of Europe. ${ }^{7}$ Despite these developments, it is still not entirely clear what the justifications are for a youth-specific approach to the right to counsel and what its implications are or should be.

This article aims to clarify the underlying rationale and significance of a youth-specific approach to the right to legal counsel at the stage of police interrogations on the basis of an interdisciplinary analysis of ECtHR case law, international children's rights standards and developmental psychological insights regarding this issue. In addition, this article aims to position this right in the particular context of the Dutch juvenile justice system and provide concrete recommendations to the Dutch legislator.

After a brief introduction to the Dutch juvenile justice system (\$2) followed by an overview of developments regarding the juvenile's right to counsel at the stage of police interrogations in the Netherlands, influenced by the ECtHR case law ( $\$ 3)$, we zoom in on the youthspecific approach to the right to legal counsel in ECtHR case law and international children's rights standards (\$4). Subsequently, we provide a developmental psychological perspective to the right to counsel at the stage of police interrogations $(\$ 5)$. Then, we position the youthspecific approach to the right to legal counsel in the particular context of the Dutch juvenile justice system, including recent legislative developments $(\$ 6)$, followed by some concluding remarks $(\$ 7)$.

\section{The Dutch Juvenile Justice System: A Dual Approach}

The Netherlands has a separate juvenile justice system for minors ${ }^{8}$ between age 12 and 18 . The rules governing this separate juvenile justice system are not laid down in a specific juvenile justice Act, but can be found in the Code of Criminal Procedure (CCP) and the Criminal Code (CC) which are applicable to both adults and juveniles, but provide for several specific provisions regarding the prosecution, adjudication and sanctioning of juveniles. Consequently, the Dutch juvenile justice system strongly corresponds to its adult equivalent. Similar to the Dutch adult criminal justice system, the justification for imposing juvenile justice interventions lies in the individual's culpability and responsibility for committing an offence. ${ }^{9}$ Core substantive notions in the Dutch adult criminal justice system, such as culpability, are equally present in the juvenile justice system. The same applies for the descriptions of the offences as laid down in the CC and most of the procedural rules embodied in the CCP, inter alia, concerning the application of coercive measures during the pre-trial investigation. ${ }^{10}$

Nevertheless, the Dutch juvenile justice system clearly has a different character, which lies in its pedagogical approach. ${ }^{11}$ This approach distinguishes the juvenile justice system from the adult criminal justice system and is operationalised through a number of specific procedural rules for juveniles, including a court appointed lawyer, trial in a youth court (in camera), a special role for the Child Care and Protection Board and the involvement of parents, among others in the first stages of criminal proceedings (Articles 486-509 of the CCP). In addition, there is a separate penal system (Articles 77a-77kk of the CC), which contains different, less severe sentences and a strong focus on education, behaviour modification and recidivism reduction. Additionally, specialised professionals and organisations, such as the already mentioned Child Care and Protection Board, the Youth Probation Office and special juvenile institutions, are involved in all stages of the juvenile justice procedure and enforcement of sentences. The existence of youth-specific procedural provisions, sanctions and institutions boils down to the acknowledgement that juveniles cannot yet be considered fully developed and accountable, and therefore deserve a special approach that takes into account their age and level of maturity. ${ }^{12}$

The primary objective of Dutch juvenile justice is (re-)education, reintegration and prevention of recidivism (special prevention), although retribution, general prevention (deterrence), protection of society and public order and compensation for victims and society can also be considered as objectives. ${ }^{13}$ The Dutch juvenile justice system is furthermore characterised by the pivotal position of the notion of 'best interests of the child', which aims to prevent the juvenile justice system from having a negative impact on the child's short- and long-
6. This position is also defended by Advocate General Spronken, who pleads, with reference to more recent case law of the ECtHR, for embracement of the right to legal counsel during police interrogations as a fundamental part of a fair trial for all arrested suspects in the Dutch criminal justice system, regardless of their age. See Legal Opinion of A-G Spronken, 26 November 2013, ECLI:NL:PHR:2013:1424.

7. Commission proposal of 27 November 2013 for a directive of the European Parliament and of the Council on procedural safeguards for children suspected or accused in criminal proceedings (COM(2013)822 final).

8. We refer to minors, children or juveniles as persons under the age of 18 when they allegedly committed an offence, falling under the scope of juvenile justice. In addition, we write in a masculine form.
9. I. Weijers, 'Grondslagen van jeugdstrafrecht', in I. Weijers and F. Imkamp (eds.), Jeugdstrafrecht. In internationaal perspectief (2011) 31; G. de Jonge and A.P. van der Linden, Handboek Jeugd \& Strafrecht (2013), at 77 ff. and 181 ff.; J. Uit Beijerse, Jeugdstrafrecht. Beginselen, wetgeving en praktiik (2013), at 13-35.

10. Ibid

11. Ibid.

12. Ibid.

13. M.R. Bruning et al., Wegwijs in het jeugdsanctierecht (2010). 
term interests (cf. Article 3(1) and 40(1) of the UN Convention on the Rights of the Child; CRC). ${ }^{14}$

In conclusion, the Dutch juvenile justice system recognises the need for a specialised juvenile oriented, pedagogical approach with a firm focus of both eyes on the child's (future) behaviour and the prevention of negative effects on the child's best interests and development while safeguarding the right to a fair trial. The concrete implications of this dual approach depend on the phase of the juvenile justice system.

\section{Juveniles' Right to Counsel: An Overview of Recent Developments}

\subsection{ECtHR Case Law: Salduz and Panovits}

In November 2008, the Grand Chamber of the ECtHR issued a landmark ruling in the case of Salduz v. Turkey, in which it leaves no doubt that the right to a fair trial as laid down in Article 6(1) of the ECHR requires that 'access to a lawyer should be provided as from the first interrogation of a suspect by the police' ${ }^{15}$ This right may only be restricted when the authorities demonstrate in the light of the particular circumstances of each case that there are compelling reasons to do so. According to the Court, 'the rights of the defence will in principle be irretrievably prejudiced when incriminating statements made during police interrogation without access to a lawyer are used for a conviction'. As to this, the Court explicitly emphasised 'the fundamental importance of providing access to a lawyer where the person in custody is a minor'. ${ }^{16}$

Shortly after the Salduz judgment, the ECtHR issued a judgment in the case of Panovits v. Cyprus, in which it further elaborates on the juvenile's right to counsel at the initial stages of police interrogation. The Court ruled, on the basis of youth-specific considerations that underscore the particular capacities and vulnerability of minors in the context of police interrogations, ${ }^{17}$ that minors are entitled to legal or other assistance during police interrogations in order to enable them to participate effectively in the proceedings, which is an important part of the right to a fair trial. ${ }^{18}$ Nevertheless, the Court makes clear that the minor's possibility to waive his right to counsel must be recognised, although it places the authorities under special scrutiny. ${ }^{19}$

Thus, under the case law of the ECtHR, the right to counsel as from the initial stages of criminal justice is considered a fundamental value of the right to a fair tri-

\footnotetext{
14. I. Weijers, 'Grondslagen van jeugdstrafrecht', in I. Weijers and F. Imkamp (eds.), Jeugdstrafrecht. In internationaal perspectief (2011) 31, at 49-51.

15. Salduz v. Turkey, ECHR (2008) No. 36391/02, para. 55

16. Ibid., para. 60.

17. See para. 4.1

18. Panovits v. Cyprus, ECHR (2008) No. $4268 / 04$, paras. 67 and 68 .

19. Ibid., para. 68.
}

al, with particular relevance for the position of minors subjected to police interrogations, as individuals in need of additional protection.

\subsection{Dutch Supreme Court}

In the Netherlands, the rulings of the European Court of Human Rights in Salduz and Panovits led to commotion amongst legal scholars, law practitioners and policymakers alike. Although the exact implications of this new ECtHR case law were not utterly clear, ${ }^{20}$ it was assumed that the Dutch system did not meet the requirements set out in the ECtHR judgments, since Dutch law did not provide for a suspect's right to legal counsel as early as the initial stage of police interrogations.

On the 30th of June 2009, the Dutch Supreme Court provided clarity by issuing rulings in three cases, in which it interprets the standards set by the ECtHR and their implications for the Dutch criminal and juvenile justice system. ${ }^{21}$ The Supreme Court considered that every arrested suspect ${ }^{22}$ has the right to consult a lawyer before the first police interrogation. This means that, prior to the first police interrogation, the arrested suspect should be sufficiently informed about his right to consult a lawyer. Apart from the situation in which the suspect - explicitly or silently, yet unequivocal$1 y^{23}$ - expresses a wish to waive this right or in case compelling reasons justify denial of access to a lawyer, the authorities should take all reasonable steps to ensure that the suspect fully enjoys his right to consult a lawyer prior to police interrogation. ${ }^{24}$ When the authorities fail to meet this obligation, incriminating statements made by the suspect during the police interrogation cannot be used as evidence for a conviction. ${ }^{25}$

The Supreme Court made clear that these considerations regarding the right to consult a lawyer prior to police interrogation apply for all arrested suspects, both adults and minors. Yet, as to minors in particular, the

20. They remain subject to debate. One specific issue concerns the question as to what extent the ECtHR has proclaimed that a suspect has the right to have his or her lawyer present during police interrogations. See the debate in NJB: M.J. Borgers, 'Een nieuwe dageraad voor de rechtsbijstand bij het politieverhoor?', 61 NJB 88 (2009); T.N.B.M. Spronken, 'Ja, de zon komt op voor de raadsman bij het politieverhoor!', 62 NJB (2009); A.J.M. de Swart, 'Toch nog een raadsman bij het politieverhoor?', 166 NJB (2010); A.J.M. de Swart, ‘Update Salduz-doctrine. Toch nog een raadsman bij het politieverhoor? Part II', 2190 NJB (2010); M.J. Borgers, 'De ijdele hoop van Pishchalnikov en Brusco', 166 NJB (2010); J.T.C. van Lelieveld and P. van Kampen, 'Rechtsbijstand in de voorfase van het strafproces', 2191 NJB (2013). See also: A. Beijer, 'False Confessions during Police Interrogations and Measures to Prevent Them', 18 Eur. J. Crime Crim. L. \& Crim. Just. 311, at 312-13 (2010); C.H. Brants, 'The Reluctant Dutch Response to Salduz', 15 EdinLR 298 (2011)

21. Dutch Supreme Court, 30 June 2009, ECLI:NL:HR:2009:BH3081.

22. The Dutch Supreme Court repeatedly emphasised that, in principle, only arrested suspects enjoy the Salduz right to legal counsel. See: Dutch Supreme Court, 9 November 2010, ECLI:NL:HR:2010:BN7727; Dutch Supreme Court, 11 June 2013, ECLI:NL:HR:2013:CA2555.

23. Cf. Dutch Supreme Court, 21 January 2014, ECLI:NL:HR:2014:133, paras. 3.5 and 3.6.

24. Dutch Supreme Court, 30 June 2009, ECLI:NL:HR:2009:BH3081, para. 2.5 .

25. Ibid., paras. 2.7.1-2.7.3 
Supreme Court ruled that they also have an additional right to assistance by a lawyer or another 'person of trust' during the police interrogations. ${ }^{26}$ The Dutch Supreme Court, thus, interpreted the right to (legal) assistance as from the initial stage of police interrogations under Article 6 of the ECHR significantly broader when minors are concerned.

\subsection{Dutch Policy Directive on Legal Counsel at Police Interrogation}

The Dutch Supreme Court pointed out that it is up to the legislator or policymakers to draft general guidelines regulating the right to have access to legal counsel in the initial stages of police interrogation. ${ }^{27}$ Against this background, the Board of Procurators General drafted the Aanwijzing Rechtsbijstand Politieverhoor (Policy Directive on Legal Counsel at Police Interrogation) in 2010, outlining the official Dutch policy regarding the right to legal counsel for both adults and minors at the stage of police interrogation. ${ }^{28}$

According to the Directive, the scope of the right to counsel in the initial stage of the police interrogations depends on the severity of the case and the vulnerability of the suspect. The latter represents the recognition of the particular position of minors. The Directive stipulates that minors accused of an offence have the right to legal counsel prior to police interrogation and the right to assistance by a lawyer or another representative during police interrogation. With regard to the right to waive legal or other appropriate assistance, the Directive distinguishes between different groups of minors according to age and seriousness of the offence. When it comes to 12 - to 15 -year-olds, there is no possibility to waive the right to prior consultation of a lawyer in case the accusation concerns a felony for which the use of pre-trial detention is allowed by law (i.e. a severer offence); yet in case of specific minor offences or misdemeanours, this group of minors can waive their right to counsel. As far as 16- and 17-year-olds are concerned, the right to prior consultation cannot be waived in case of the most serious felonies (i.e. a violent or sexual assault such as murder, homicide/manslaughter, rape, etc.); however, it can be done if the charge concerns a less serious offence or a misdemeanour.

During his consultation of a lawyer, the minor can decide whether or not to exercise the right to counsel during the interrogation. If a minor waives his right to consult a lawyer prior to the police interrogation, this automatically implies a waiver of his right to legal assistance during police interrogations. If a minor waives his right to legal assistance, he remains entitled to have a 'person of trust' present during the police interrogations. This person of trust could be one of his parents or legal guardians or another confidant of the minor. A person of trust has no independent right to be present

26. Ibid., para. 2.6

27. Dutch Supreme Court, 30 June 2009, ECLI:NL:HR:2009:BH3081, para. 2.4 .

28. 'Aanwijzing Rechtsbijstand Politieverhoor', Bulletin of Acts and Decrees, at 4003 (2010). during the police interrogations; it is up to the minor to decide. Besides, the presence of a person of trust during police interrogations is only permitted when there is no lawyer present.

As to the role of the lawyer during the police interrogation, the Policy Directive provides that a reticent approach is required in order to limit the lawyer's influence on the interrogations (i.e. process of truth finding) as much as possible. The lawyer's main task is to observe possible police inflicted unlawful pressure on the minor and to make sure that the minor understands the questions and the transcription of the interrogation. As far as the person of trust is concerned, the Policy Directive prescribes that he is not allowed to interrupt the interrogation or to make contact with the suspect during the police interrogation, but does not provide further clarity about the function of the person of trust during the interrogation.

The question to what extent a minor should have the right to waive his right to consult a lawyer prior to the police interrogation has been addressed by Dutch courts. The Dutch District Court of Amsterdam ruled in 2009 that minors should not have the opportunity to waive their right to consult a lawyer, because of their susceptibility to pressure and the lack of capacity to oversee the consequences of their decisions. ${ }^{29}$ Other courts, however, including the Amsterdam Criminal Court of Appeal ruled that the right to waive legal counsel should be upheld, but places authorities under scrutiny as stipulated by the European Court of Human Rights. ${ }^{30}$

\subsection{Dutch Forthcoming Statutory Legislation}

In 2011, the Dutch legislator presented the first draft of a bill, which aims to implement the abovementioned ECtHR case law in Dutch statutory legislation. The Draft Bill builds further on the Policy Directive on Legal Counsel at Police Interrogation, although there are some differences. For example, the legislative proposal explicitly chooses to implement a juvenile's right to legal counsel rather than other forms of assistance (e.g. assistance by one of the parents). Moreover, the proposal abandons the distinction between 12- to 15-year-olds and 16- and 17-year-olds, as established in the abovementioned (Dutch) Directive. According to the proposal, every minor from 12 to 17 years of age who is suspected of committing an offence is entitled to consultation with a lawyer prior to the first police interrogation, without the possibility of waiver, also when it concerns minor offences (e.g. so-called HALTfeiten, which can be settled by a police diversion intervention). In addition, the juvenile can decide whether or

29. District Court Amsterdam, 13 November 2009, ECLI:NL:RBAMS 2009:BK4115 and 24 September 2009, No. 13/854677-09 (unpublished); see also M.R. Bruning, 'Salduz/Panovits bij jeugdstrafzaken; het volle pond of een onsje minder?', 32-2 FJR 21 (2010).

30. Amsterdam Court of Appeal, 9 December 2010, ECLI:NL:GHAMS: 2010:BO8217, BO8219, BO8221 and BO8230; see also District Court of Haarlem, 10 November 2009, ECLI:NL:RBHAA:2009:BK3403 and District Court of The Hague, 3 September 2009, ECLI:NL:RBSGR: 2009:BJ7233. 
not to exercise the right to counsel during the interrogation. He can make his decision on the basis of the consultation with the lawyer prior to the interrogation. ${ }^{31}$

In 2011, the Dutch legislative process was put on a hold, while waiting for the outcome of the pending EU 'legislative' developments. More than two years later, on the 22 October 2013, the EU Directive (2013/48/EU) on the right of access to a lawyer in criminal proceedings came into force. ${ }^{32}$ In February 2014, the State Secretary divided the 2011 Draft Bill into two separate draft bills. One draft bill specifically aims to implement the EU Directive (2013/48/EU). The other draft bill adds some new provisions that regulate the early stage of the criminal investigation. When it comes to the dismissal of the juvenile's right to waiver and the legislator's explicit choice to implement the right to legal counsel rather than other types of assistance during police interrogations, the 2014 Draft Bill on implementing EU Directive (2013/48/EU) remains the same compared to the 2011 Draft Bill. ${ }^{33}$

\subsection{Directive 2013/48/EU and Other EU Developments}

EU Directive 2013/48/EU obliges Member States to regulate the right to legal counsel at the stage of police interrogation in statutory legislation in accordance with the minimum standards as provided in the Directive. The way in which Member States live up to their obligation to implement these minimum standards is largely left to their discretion.

The EU Directive itself does not provide much guidance regarding the particular legal position of juveniles at the stage of police interrogations, apart from the general remark in the Preamble that the Directive 'promotes the rights of children and takes into account the Guidelines of the Council of Europe on child friendly justice' and 'ensures that suspects and accused persons, including children, are provided with adequate information to understand the consequences of waiving a right and that any such waiver is made voluntarily and unequivocally'. ${ }^{34}$ The only (indirect) reference to the legal position of accused juveniles at the stage of police interrogation in the actual provisions of the Directive might be Article 13: 'Member States shall ensure that the particular needs of vulnerable suspects and vulnerable accused persons are taken into account in the application of this Directive.'

Consequently, it is largely up to the Dutch legislator to determine - on the basis of ECtHR case law and other relevant sources - the legal position of accused juveniles at the stage of police interrogations in the forthcoming statutory act. However, it is to be expected that the EU will also adopt a youth-specific Directive on procedural safeguards for children suspected or accused in criminal proceedings, which aims to give more specific guidance

31. See Explanatory Memorandum, Arts. 489 (new) and 490 (new) of the CCP.

32. EU Directive 2013/48/EU, OJ 2013 L 294/1.

33. This article covers legislative developments until the 15th of June 2014.

34. EU Directive 2013/48/EU, OJ 2013 L 294/1, at preamble, para. 55. to the domestic legislator. ${ }^{35}$ Some key features of this proposal are mandatory access to a lawyer (i.e. no right to waive the right to access, save in case of some minor offences; Article 6) and audiovisual recordings of police interrogations (Article 9).

Having discussed the recent European and national developments, it is time to look in more detail at the justifications for a youth-specific approach and its implications. We will, first, go briefly back to the Salduz and Panovits cases to take a closer look at the considerations that lie at the heart of the ECtHR's youth-specific approach and to analyse these in the context of (other) international children's rights standards, including the UN Convention on the Rights of the Child and related UN resolutions, two of the General Comments of the UN Committee on the Rights of the Child and relevant children's rights standards developed by the Council of Europe.

\section{Juveniles' Right to Counsel: A Children's Rights Perspective}

4.1 The ECtHR's Youth-Specific Approach The European Court's Grand Chamber judgment in Salduz v. Turkey explicitly recognises the right to legal assistance for minors as from the first interrogation of a suspect by the police as an essential part of the right to a fair trial under Article 6(1) ECHR. The European Court elaborates on this and provides more clarity in Panovits v. Cyprus by emphasising that children involved in criminal proceedings 'shall be dealt with in a manner which takes full account of their age, level of maturity and intellectual and emotional capacities' and by stressing that the authorities should take action to encourage the child's ability to understand and participate in the proceedings. ${ }^{36}$ In addition, the Court underscores that 'the right of an accused minor to effective participation in his or her criminal trial requires that he be dealt with, with due regard to his vulnerability and capacities from the first stages of his involvement in a criminal investigation and, in particular, during any questioning by the police'. ${ }^{37}$ As to this, the Court urges the authorities to take action 'to reduce as far as possible the minor's feelings of intimidation and inhibition and ensure that the accused minor has a broad understanding of the nature of the investigation, of what is at stake for him or her, including the significance of any penalty which may be imposed as well as of his rights of defence and, in particular, of his right to remain silent' ${ }^{38}$ It

35. Commission proposal of 27 November 2013 for a directive of the European Parliament and of the Council on procedural safeguards for children suspected or accused in criminal proceedings (COM(2013)822 final).

36. Panovits v. Cyprus, ECHR (2008) No. 4268/04, para. 67.

37. Ibid.

38. Ibid. 
means that the minor 'if necessary with the assistance of, for example, an interpreter, lawyer, social worker or friend, should be able to understand the general thrust of what is said by the arresting officer and during his questioning by the police'. ${ }^{39}$

When it comes to the minor's possibility of waiving the right to counsel, the Court emphasises the particular vulnerability of an accused minor and the imbalance of power, which is inherent to the very nature of criminal proceedings. ${ }^{40}$ This leads to the Court's conclusion that waiving the minor's right to counsel during police interrogation by him or on his behalf should be subject to extra scrutiny on the side of the authorities. A waiver can only be accepted 'where it is expressed in an unequivocal manner after the authorities have taken all reasonable steps to ensure that he or she [the juvenile] is fully aware of his rights of defence and can appreciate, as far as possible, the consequence of his conduct'. ${ }^{41}$

The Court's abovementioned considerations clearly indicate a recognition of the particular importance of the right to counsel at the stage of the first police interrogations when minors are concerned; it is considered an essential part of the minor's right to a fair trial under Article 6 of the ECHR, which also includes his right to participate effectively in the proceedings. As to its youth-specific approach, the Court seems inspired by the international framework of children's rights, consisting of the UN Convention on the Rights of the Child (CRC) and specific provisions in international human rights treaties and other legal instruments. In Salduz v. Turkey, the Court explicitly refers to, amongst others, Article 37 of the CRC and General Comment No. 10 of the UN Committee on the Rights of the Child. ${ }^{42}$ In Panovits v. Cyprus, the Court brings up the provision of Article 14(4) of the ICCPR, which prescribes that when juveniles are concerned, the criminal justice procedure will take account of their age and the desirability of promoting their rehabilitation. ${ }^{43}$

Moreover, in the Panovits case, the Court reconfirms its previous case law, in which it has built its youth-specific approach to Article 6 of the ECHR amongst others on children's rights standards developed by the United Nations and the Council of Europe. ${ }^{44}$ In this regard, it is important to point at $T \mathrm{v}$. United Kingdom, in which the Court ruled, with explicit reference to Article 40 of the CRC, that 'a child charged with an offence [must be] dealt with in a manner which takes full account of his age, level of maturity and intellectual and emotional capacities, and that steps are taken to promote his ability

39. Ibid

40. Ibid., paras. 67 and 68

41. Ibid., para. 68. After Panovits the ECtHR issued various other judgments, which elaborated upon the ruling of the Grand Chamber in Salduz, but without concrete implications for minors; see for an overview e.g. P. van Kampen and J. Leliveld, 'Rechtsbijstand in de voorfase van het strafproces', 2191 NJB 2604 (2013).

42. Salduz v. Turkey, ECHR (2008) No. 36391/02, paras. 34 and 35.

43. Panovits v. Cyprus, ECHR (2008) No. 4268/04, para. 41.

44. See: Panovits v. Cyprus, ECHR (2008) No. 4268/04, para. 67 in conjunction with T. v. the United Kingdom, ECHR (1999) No. 24724/94, paras. 43 and 44 to understand and participate in the proceedings' ${ }^{45}$ This ruling underscores that there are specific requirements for effective participation of juveniles as part of their right to a fair trial (Article 6 of the ECHR), which according to Kilkelly is 'a persuasive restatement of the fundamental nature of these rights' ${ }^{46}$ The Court has also ruled, in S.C. v. United Kingdom, that the right to effective participation does not imply that the juvenile should 'understand or be capable of understanding every point of law or evidential detail', but that he 'has a broad understanding of the nature of the trial process and of what is at stake for him or her. ${ }^{47}$ In light of this, the right to legal or other representation is regarded essential. $^{48}$

\subsection{International Children's Rights Standards}

The case law of the ECtHR is strongly connected with the approaches towards juveniles suspected or accused of committing crimes as reflected by international (UN) and regional (for this purpose Council of Europe) children's rights standards.

\subsubsection{United Nations}

Since 1985, the United Nations (UN) has developed several standards to improve and safeguard the legal position of children in the juvenile justice system, including the 1985 Standard Minimum Rules for the Administration of Juvenile Justice (the 'Beijing Rules'), the 1990 Rules for the Protection of Juveniles Deprived of their Liberty (the 'Havana Rules'), the 1990 Guidelines for the Prevention of Juvenile Delinquency (the 'Riyadh Guidelines') and most importantly the 1989 UN Convention on the Rights of the Child (CRC). In 2007 the UN Committee on the Rights of the Child issued a General Comment on the meaning and implications of the relevant provisions of the CRC (primarily Articles 40 and 37) for the juvenile justice system at the domestic level ('General Comment No. 10'). ${ }^{49}$ This serves as recommendation to States Parties that have ratified the CRC (i.e. at the time of writing, all $193 \mathrm{UN}$ Member States, except the United States, Somalia and South Sudan). ${ }^{50}$

These UN children's rights standards touch upon the juvenile's right to legal counsel at the stage of police interrogations. Article 40(2)(b)(ii) of the CRC requires that every child has the right 'to be informed promptly and directly of the charges against him or her, and, if appropriate, through his or her parents or legal

45. T. v. the United Kingdom, ECHR (1999) No. 24724/94, para. 84. See also V. v. the United Kingdom, ECHR (1999) No. 24888/94.

46. U. Kilkelly, 'CRC in Litigation under the ECHR', in T. Liefaard and J.E. Doek, Litigating the Rights of the Child (to be published in 2014).

47. S.C. v. the United Kingdom, ECHR (2004) No. 60958/00, para. 29.

48. Ibid., para. 29.

49. General Comment No. 10, Children's rights in juvenile justice, UN Doc. $\mathrm{CRC} / \mathrm{C} / \mathrm{GC} / 10$

50. Although the Beijing Rules, Havana Rules and Riyadh Guidelines are as UN Resolutions strictly not legally binding, the UN Committee on the Rights of Child urges CRC member states to incorporate these standards in domestic juvenile justice policies and legislation; see General Comment No. 10, Children's rights in juvenile justice, UN Doc. CRC/C/ $\mathrm{GC} / 10$, para. 4 
guardians, and to have legal or other appropriate assistance in the preparation and presentation of his or her defence'. Furthermore, Article 40(2)(b)(iii) of the CRC requires that children accused of a criminal offence have the right to a fair hearing before a competent, independent and impartial authority or judicial body, in the presence of legal or other appropriate representation as well as his parents or legal guardians. Legal or other appropriate assistance is regarded a fundamental element of a child's right to a fair trial. Particularly with regard to assistance of children deprived of their liberty, among others in the context of juvenile justice (i.e. arrest, detention or imprisonment), Article 37(d) CRC stipulates that 'every child deprived of his or her liberty shall have the right to prompt access to legal and other appropriate assistance', which implies, among others, that a child should receive immediate access to legal and other appropriate assistance after arrest. ${ }^{51}$

The Beijing Rules and Havana Rules enshrine similar provisions. If a juvenile were arrested or held in pretrial detention, Rule 18(a) of the Havana Rules provides that the juvenile 'should have the right of legal counsel and be enabled to apply for free legal aid, where such aid is available'. Moreover, Rule 15.1 of the Beijing Rules underscores that the juvenile has the right to be represented by a legal adviser or to apply for free legal aid 'throughout the proceedings'. Rule 15.2 adds that parents or the guardian has the right to participate in the proceedings as long as this serves the interest of the juvenile. According to the commentary to these Beijing Rules provisions, legal counsel and free legal aid are required to provide the juvenile with legal assistance, whereas the participation of the parents or guardian should be regarded as 'general psychological and emotional assistance to the juvenile' throughout the entire procedure.

Neither the CRC nor the Beijing Rules and Havana Rules explicitly recognise legal and/or other appropriate assistance at the stage of the first police interrogations. However, this seems to be implied. According to the UN Committee on the Rights of the Child in its General Comment No. 10, the right to presence of legal representation under Article 40(2)(b)(iii) CRC 'should not be limited to the trial before the court or other judicial body, but also applies to all other stages of the process, beginning with the interviewing (interrogation) of the child by the police'. ${ }^{52}$ Legal assistance at all stages of the proceedings should guarantee that all decisions in the context of the juvenile justice proceedings are 'the result of a process in which the human rights of the child and legal safeguards are fully respected'. ${ }^{53}$ The

51. T. Liefaard, Deprivation of Liberty of Children in Light of International Human Rights Law and Standards (2008), at 209. Note that Art. 37(d) of the CRC aims to protect the right to liberty, while Art. 40 of the CRC safeguards the right to a fair trial. In addition, it is interesting that Art. 37(d) of the CRC is formulated cumulatively: 'legal and other appropriate assistance'.

52. General Comment No. 10, Children's rights in juvenile justice, UN Doc. CRC/C/GC/10, para. 52.

53. Ibid., para. 52.
Committee explicitly recognises the juvenile's right to legal counsel at the stage of police interrogations under the CRC. Additionally, the Committee highlights that parents or legal guardians should also be present at the juvenile's police interrogation 'because they can provide general psychological and emotional assistance to the child'. ${ }^{54}$ This does not mean, according to the Committee, that parents can act in defence of the child. ${ }^{55}$

Furthermore, in its commentary to Article 40(2)(b)(iv) of the CRC, the Committee reiterates that 'the child being questioned [by the police] must have access to a legal or other appropriate representative, and must be able to request the presence of his/her parent(s) during questioning', since this is vital for the protection of children against compulsory self-incrimination. ${ }^{56}$ According to the Committee, there is a need for 'independent scrutiny of the methods of interrogation to ensure that the evidence is voluntary and not coerced, given the totality of the circumstances, and is reliable' ${ }^{57}$ The presence of legal or other counsel, parent(s), or independent representatives of the child during the juvenile's police interrogations should therefore be an important factor in the court's determination of the voluntary nature and reliability of a confession before using it as evidence. ${ }^{58}$

Moreover, the UN Committee on the Rights of the Child emphasises that children have the right to effectively participate during all stages of the juvenile justice proceedings. ${ }^{59}$ Effective participation in the proceedings is a right that can be derived from the child's fundamental right to be heard (Article 12(1) and (2) of the CRC) and can be considered an essential requirement of a fair trial (Article 40(2) of the CRC) ${ }^{60}$ Effective participation implies that the child should be sufficiently informed of the charges and the juvenile justice procedures, including the possible sentences that could be imposed. ${ }^{61}$ In fact, according to the Committee, the child should be provided with enough information to have an active role in determining his defence strategy. ${ }^{62}$ Legal assistance, free of charge, should be regarded a prerequisite of effective participation. ${ }^{63}$ Since the first police interrogation (i.e. the suspect's initial choice whether to make use of his right to remain silent or to testify to the police) is crucial for the defence strategy in the entire case, it can be concluded that the child's right to have an active role in determining the defence strategy under the CRC

54. Ibid., para. 53. This seems to link up with the cumulative wording of Art. 37(d) of the CRC

55. Ibid., para. 53. Note that Dutch law stipulates that parents act in the defence of their child; Art. 496 2) of the CCP.

56. Ibid., paras. 57 and 58 .

57. Ibid., para. 58.

58. Ibid., para. 58.

59. Ibid., para. 44.

60. Ibid., paras. 43-46.

61. Ibid., para. 44. See also Dutch Supreme Court, 28 August 2012, ECLI:NL:PHR:2012:BX3807 (see Conclusion of A-GI Vellinga).

62. General Comment No. 10, Children's rights in juvenile justice, UN Doc. CRC/C/GC/10, para. 46.

63. Ibid., para. 49. 
should imply a right to legal counsel as from the first police interrogation.

The Committee does not address the right to waiver nor does the CRC provide such a right. In this regard, there is some ambivalence about the legal position of the child. With reference to Article 12 of the CRC, the Committee strongly states that it is the right of the child to be heard directly (i.e. not only through a representative) and that '[t]his right must be fully observed at all stages of the process, starting with the [the] pre-trial stage when the child has the right to remain silent, as well as the right to be heard by the police [... ${ }^{64}$ This seems to leave room for acceptance of leeway for the child to waive his right to consult a lawyer. ${ }^{65}$ At the same time, the Committee seems to proclaim a more protective approach, meaning that a child should be legally represented in order to safeguard his right to effectively participate throughout the process and have his fair trial rights adequately protected. ${ }^{66}$ In light of the latter approach, the Committee underscores that 'other appropriate assistance is possible (e.g. social worker), but [that] that person must have sufficient knowledge and understanding of the various legal aspects of the process of juvenile justice and must be trained to work with children in conflict with the law' ${ }^{67}$

\subsubsection{Council of Europe}

At the European level, the Council of Europe has developed various children's rights standards that specifically focus on children in the juvenile justice system. Some of these standards are relevant for the right to legal counsel at the stage of the police interrogations.

The European Rules for juvenile offenders subject to sanctions and measures (2008) stipulate that juvenile justice systems should ensure the juvenile's effective participation in the proceedings (Rule 13). According to the commentary to this provision, effective participation implies that the juvenile is provided with legal assistance. ${ }^{68}$ When deprivation of liberty of the juvenile is a possibility, the juvenile has a right to legal counsel as from 'the outset of the procedure'. ${ }^{69}$ The European Committee for the Prevention of Torture (CPT) has also emphasised the significance of access to legal assistance at the stage of police interrogations. ${ }^{70}$ The CPT also urgently requested more attention for the particular

64. Ibid., para. 44.

65. This seems to find support in the Committee's general approach to the right to be heard in General Comment No. 12, The Right of the child to be heard, UN Doc. CRC/C/GC/12, para. 35: 'After the child has decided to be heard, he or she will have to decide how to be heard: "either directly, or through a representative or appropriate body." The Committee recommends that, wherever possible, the child must be given the opportunity to be directly heard in any proceedings.' See also General Comment No. 12, The Right of the child to be heard, UN Doc. CRC/C/ $\mathrm{GC} / 12$, para. $58 \mathrm{ff}$

66. General Comment No. 10, Children's rights in juvenile justice, UN Doc. CRC/C/GC/10, para. 49.

67. Ibid.

68. $C M(2008) 128$ addendum 1.

69. Ibid.

70. CPT Standards (CPT/Inf/E (2002) 1 - Rev. 2013), at 15-16; see also at $83 \mathrm{ff}$. for more detailed guidance on the position of juveniles deprived of their liberty. vulnerability of juveniles during police custody during the drafting of the Rules. ${ }^{71}$ According to the CPT, the Rules should expressly prescribe that juveniles in police custody 'shall not be required to make any statement or sign any document related to the offence of which they are suspected without a lawyer and/or a trusted person being present and assisting them' ${ }^{72}$

Although the European Rules for Juvenile Offenders were not altered accordingly, a comparable standard has been incorporated in the Guidelines on Child Friendly Justice (2010). Guideline 30 stipulates that 'a child who has been taken into custody should not be questioned in respect of criminal behaviour, or asked to make or sign a statement concerning such involvement, except in the presence of a lawyer or one of the child's parents or, if no parent is available, another person whom the child trusts' ${ }^{73}$

\subsection{Protection and Effective Participation}

When taking into account international children's rights standards, the child's right to legal counsel as from the stage of police interrogations can be regarded as an essential requirement for a fair trial for two reasons. First, because children in particular, given their dependency and vulnerability, should be protected against self-incrimination or the use of physical or mental force and other human rights violations during police interrogations. Second, legal assistance in the early stage of the police interrogations is crucial for enabling the child to participate effectively in the proceedings.

Taken together, these two notions embody the ambivalent image of the child that lies at the heart of the international framework of children's rights as it is embedded in the CRC. ${ }^{74}$ On the one hand, children are considered to be particularly vulnerable, because they are not yet fully developed - both physically and psychologically - and have specific emotional and educational needs. Consequently, they are entitled to special protection and care. ${ }^{75}$ On the other hand, the CRC clearly expresses the recognition of the child as a subject of rights and as an individual who should be considered capable to exercise his own rights and of making his own decisions, in accordance with the child's evolving capacities (Article 5 of the CRC). In light of this, States Parties are called upon to set a minimum age of criminal responsibility (MACR), above which a child can be held accountable, which may very well come with an assumed capacity to participate independently in criminal justice proceedings (see, e.g., GC No. 10, para. 45). The child furthermore has a right to be heard which should be respected, and his opinion has to be given due

71. CPT, 18th General Report (2007-2008), para. 24

72. Ibid., para. 24.

73. Guidelines of the Committee of Ministers of the Council of Europe on child-friendly justice (2010).

74. See also e.g. T. Liefaard, 'Child Soldiers: Towards a Rights Based Imagery', in C. Brants, A. Hol \& D. Siegel (eds.), Transitional Justice. Images and Memories (2013) 161

75. See Preamble of the CRC. See also General Comment No. 10, Children's rights in juvenile justice, UN Doc. CRC/C/GC/10, para. 10. 
weight in according with his age and maturity. These rights also affect juvenile justice proceedings. ${ }^{76}$

International children's rights standards are not entirely clear whether children have the right to waive their right to counsel. As to this, one may question to what extent the particularly difficult context of the first police interrogations is reason enough to let protection outweigh the assumed (relative) autonomy of the child for the sake of his future best interests, as is suggested by the recent EU Commission proposal and the Dutch draft bills.

In light of the pedagogical objectives of juvenile justice, one may query what can be learned from development psychological research on the value of legal counsel in the earliest stages of criminal justice proceedings, in particular on the issue of children and police interrogations. This will be addressed in the next paragraph.

\section{Juveniles' Right to Counsel: A Developmental Psychological Perspective}

\subsection{Developmental Psychological Research}

There is an extensive body of developmental psychological and empirical research on police interrogations of juveniles available, particularly in the United States. The juvenile's ability to understand and exercise socalled Miranda rights $^{77}$ (i.e. the right to remain silent and the right to legal counsel prior to, and during police interrogations) has been the subject of research by numerous American scholars. Among others, Thomas

76. See Art. 12 CRC. See also General Comment No. 12, The Right of the child to be heard, UN Doc. CRC/C/GC/12. See also L. Krappmann, 'The Weight of the Child's View', 18-4 International Journal of Children's Rights 501 (2010).

77. The concept of 'Miranda rights' was established in the US criminal justice system as a result of the 1966 Miranda v. Arizona case, in which the U.S. Supreme Court ruled that: 'The person in custody must, prior to interrogation, be clearly informed that he has the right to remain silent, and that anything he says will be used against him in court; he must be clearly informed that he has the right to consult with a lawyer and to have the lawyer with him during interrogation, and that, if he is indigent, a lawyer will be appointed to represent him.' See U.S. Supreme Court, Miranda v. Arizona, 13 June 1966, 384 U.S. 436.
Grisso and Barry C. Feld conducted ground-breaking research in this particular field of study. ${ }^{78}$

\subsection{Juveniles' Cognitive Ability and Maturity of Judgment}

In 2012, Feld published his latest study on juveniles and police interrogations titled Kids, Cops and Confessions, which includes a comprehensive overview of developmental psychological research and literature on this issue. ${ }^{79}$ Based on an extensive body of research, Feld underscores the importance of making a distinction between a juvenile's cognitive ability (capacity to understand) and maturity of judgment (capability to make grown-up decisions) when it comes to determining his ability to effectively exercise Miranda rights during police interrogations. ${ }^{80}$

Research indicates that - since juveniles' general intellectual ability, verbal ability, attention and executive functioning significantly improve with age - young juveniles in particular may not yet have obtained the cognitive abilities required to understand and effectively participate in juvenile justice proceedings. ${ }^{81}$ Multiple studies show that juveniles 15 years of age and younger as well as 16- and 17-year-olds with a low IQ (below 85) have far more difficulties understanding Miranda rights than adults do, even compared to adults with a low IQ. ${ }^{82}$ Most 16- and 17-year-old juveniles, however, are con-

78. See amongst others: T. Grisso, 'Juveniles' Capacities to Waive Miranda Rights: An Empirical Analysis', 68 California Law Review 1134 (1980); T. Grisso, 'The Competence of Adolescents as Trial Defendants', 3 Psychology, Public Policy \& Law 3 (1997); T. Grisso, Instruments for Assessing Understanding and Appreciation of Miranda Rights (1998); T. Grisso, 'What We Know about Youths' Capacities as Trial Defendants', in T. Grisso and R.G. Schwartz (eds.), Youth on Trial: A Developmental Perspective on Juvenile Justice (2000) 139; T. Grisso et al., 'Juveniles' Competence to Stand Trial: A Comparison of Adolescents' and Adults' Capacities as Trial Defendants', 27 Law and Human Behavior 333 (2003); B.C. Feld, 'Juveniles' Competence to Exercise Miranda Rights: An Empirical Study of Policy and Practice', 91 Minnesota Law Review 26 (2006); B.C. Feld, 'Police Interrogation of Juveniles: An Empirical Study of Policy and Practice', 97 Journal of Criminal Law and Criminology 219 (2006); B.C. Feld, Kids, Cops, and Confessions (2012).

79. B.C. Feld (2012), above n. 78

80. B.C. Feld (2012), above n. 78, at 251

81. T. Grisso (1980), above n. 78, at 1160; T. Grisso (1997), above n. 78; J. Viljoen and R. Roesch, 'Competence to Waive interrogation Rights and Adjudicative Competence in Adolescent Defendants: Cognitive Development, Attorney Contact, and Psychological Symptoms', 29 Law and Human Behavior 723 (2005), at 736; as referred to in B.C. Feld (2012), above n. 78, at 52. See also: I. Weijers and T. Grisso, 'Criminal Responsibility of Adolescents Youth as Junior Citizenship', in J. JungerTas and F. Duenkel (eds.), Reforming Juvenile Justice (2009) 45; C. Driver and E.M. Brank, 'Juveniles' Knowledge of the Court Process: Instruction from an Electronic Source', 27 Behavioral Sciences and the Law 627 (2009); as referred to in S. Rap, The Participation of Juvenile Defendants in the Youth Court (2013), at 108-9.

82. J. Viljoen, J. Klaver \& R. Roesch, 'Legal Decisions of Preadolescent and Adolescent Defendants: Predictors of Confessions, Pleas, Communication with Attorneys, and Appeals', 29 Law and Human Behavior 253 (2005); J. Viljoen and R. Roesch (2005), above n. 81; S.M. Kassin et al., 'Police-Induced Confessions: Risk Factors and Recommendations', 34 Law and Human Behavior 49 (2009); as referred to in B.C. Feld, (2012), above n. 78 , at 52-53 
sidered to be cognitively able to understand the meaning of Miranda rights. ${ }^{83}$

However, the ability to understand Miranda rights does not imply that 16- and 17-year-olds should be considered generally capable of adequately exercising Miranda rights. ${ }^{84}$ This requires 'mature decision-making competence' as well. ${ }^{85}$ Research shows that juveniles, due to their developmental stage, are generally not yet able to make 'grown-up decisions'. ${ }^{86}$ Juveniles are generally impulsive decision makers, ${ }^{87}$ who lack the ability to recognise and weigh risks in decision making, ${ }^{88}$ which is a result of juveniles' general incompetence to foresee and appreciate long-term consequences of decisions. ${ }^{89}$ This may cause juveniles, for example, to (falsely) confess for the sole purpose of ending the interrogation, without considering the negative long-term consequences of such a (false) confession. ${ }^{90}$ Besides, juveniles do not appreciate the significance of rights in the same way

83. R. Abramovitch, K.L. Higgins-Biss \& S.R. Biss, 'Young Persons' Comprehension of Waivers in Criminal Proceedings', 35 Canadian Journal of Criminology 309 (1993); R. Abramovitch, M. Peterson-Badali \& M. Rohan, 'Young People's Understanding and Assertion of Their Rights to Silence and Legal Counsel', 37 Canadian Journal of Criminology 1 (1995); M. Beyer, 'Immaturity, Culpability and Competency in Juveniles: A Study of 17 Cases', 15-2 Law and Human Behavior 125 (2000); A. Redlich, M. Silverman \& H. Steiner, 'Pre-adjudicative and Adjudicative Competence in Juveniles and Young Adults', 21 Behavioral Science \& the Law 393 (2003); J. Viljoen and R. Roesch (2005), above n. 81; A. Goldstein and N.E.S. Goldstein, Evaluating Capacity to Waive Miranda Rights (2010); as referred to in B.C. Feld (2012), above n. 78, at 53 and 251. See also: T. Grisso et al. (2003), above n. 78.

84. T. Grisso and C. Pomiciter, 'Interrogation of Juveniles: An Empirical Study of procedures, Safeguards and Rights Waiver', 1 Law and Human Behavior 321 (1977); M. Beyer, 'Immaturity, Culpability and Competency in Juveniles: A Study of 17 Cases', 15-2 Law and Human Behavior 125 (2000); as referred to in B.C. Feld (2012), above n. 78, at 53.

85. T. Grisso et al. (2003), above n. 78, at 357; B.C. Feld (2012), above n. 78 , at 251.

86. T. Grisso et al. (2003), above n. 78; as referred to in B.C. Feld (2012), above n. 78, at 55 .

87. Baird et al., 'Functional Magnetic Resonance Imaging of Facial Affect Recognition in Children and Adolescents', 38 Journal of the American Academy of Child \& Adolescent Psychiatry 195 (1999); R.E. Dahl, 'Affect Regulation, Brain Development, and Behavioral/Emotional Health in Adolescence', 6 CNS Spectrums 60 (2001); D.E. Arredondo, 'Child Development, Children's Mental Health and the Juvenile Justice System: Principles of Effective Decision-Making', 14 Stanford Law \& Policy Review 13 (2003); A. Redlich, M. Silverman \& H. Steiner, 'Preadjudicative and Adjudicative Competence in Juveniles and Young Adults', 21 Behavioral Sciences \& the Law 393 (2003); S.A. Gruber and D.A. Yurgelun-Todd, 'Neurobiology and the Law: A Role in Juvenile Justice', 3 Ohio State Journal of Criminal Law 321 (2006); as referred to in B.C. Feld (2012), above n. 78, at 49-50.

88. L. Furby and R. Beyt-Marom, 'Risk Taking in Adolescence: A DecisionMaking Perspective', 12 Developmental Review 1 (1992); W. Gardner, 'A Life-Span Rational Choice Theory of Risk Taking', in N.J. Bell and R.W. Bell (eds.), Adolescent Risk Taking (1993); T. Grisso (2000), above n. 78; E. Scott, 'The Legal Construction of Childhood', 29 Hofstra Law Review 541 (2000); as referred to in B.C. Feld (2012), above n. 78, at 48.

89. L. Steinberg, 'Cognitive and Affective Development in Adolescence', 9 Trends in Cognitive Science 69 (2005); as referred to in B.C. Feld (2012), above n. 78, at 48.

90. T. Grisso, 'Juveniles' Waivers of Rights: Legal and Psychological Competence', 3 Perspectives in Law \& Psychology (1981); L. Steinberg and E. Cauffman, 'Maturity of Judgment in Adolescence: Psychosocial Factors in Adolescent Decision-Making', 20 Law and Human Behavior 249 (1996); T. Grisso et al. (2003), above n. 78; as referred to in B.C. Feld (2012), above n. 78, at 56-57. adults do, ${ }^{91}$ which may cause juveniles to waive their rights (e.g. the right to remain silent and the right to legal counsel during police interrogations) more often and less deliberately. ${ }^{92}$ Furthermore, juveniles generally lack the competence to make autonomous decisions due to their particular susceptibility to external, social influences. ${ }^{93}$ Juveniles are very sensitive to status differences (e.g. between the interrogating police officer and the juvenile suspect) and have a general eagerness to comply with adult authority figures. ${ }^{94}$ This makes juveniles particularly vulnerable when subjected to suggestive and (psychologically) coercive interrogation techniques, ${ }^{95}$ which might cause them, for example, to (falsely) confess in order to get the much-wanted approval of the interrogator. ${ }^{96}$

\subsection{Protection and Effective Participation:}

A Developmental Psychological Perspective The lack of understanding of rights and procedures by younger juveniles and juveniles with a low IQ their lack of competence to make rational, mature decisions and their sensitivity to external, social influences make them particularly vulnerable during police interrogations. It is clear that developmental psychological research supports the underlying presumption of the international framework of children's rights that children should be considered particularly vulnerable - because they are not yet fully developed - and have specific needs, which call for a high level of protection.

In addition, these research findings give reason to carefully consider whether juveniles should be regarded capable of exercising their rights independently, particularly in the context of police interrogations. This

91. T. Grisso (1981), above n. 90; T. Grisso, 'Juvenile Competency to Stand Trial: Questions in an Era of Punitive Reform', 12-3 Criminal Justice 4 (1997); K. Larson, 'Improving the 'Kangaroo Courts': A Proposal for Reform in Evaluating Juveniles' Waiver of Miranda', 48 Villanova Law Review 629 (2003); as referred to in B.C. Feld (2012), above n. 78, at 53.

92. J. Viljoen, J. Klaver \& R. Roesch, 'Legal Decisions of Preadolescent and Adolescent Defendants: Predictors of Confessions, Pleas, Communication with Attorneys, and Appeals', 29 Law and Human Behavior 253 (2005); as referred to in B.C. Feld (2012), above n. 78, at 53.

93. B.C. Feld (2012), above n. 78, at 56.

94. G.P. Koocher, 'Different Lenses: Psycho-Legal Perspectives on Children's Rights', 16 Nova Law Review 711 (1992); K. Larson (2003), above n. 91; J. Owen-Kostelnik, N.D. Repucci \& J.R. Meyer, 'Testimony and Interrogation of Minors: Assumptions about Maturity and Morality', 61 American Psychologist 286 (2006); S.M. Kassin et al. (2009), above n. 82; as referred to in B.C. Feld (2012), above n. 78, at 56. See also: T. Grisso et al. (2003), above n. 78, at 357.

95. K. Singh and G.H. Gudjonsson, 'Interrogative Suggestibility among Adolescent Boys and Its Relationship with Intelligence, memory, and Cognitive Set', 15 Journal of Adolescence 155 (1992); G.H. Gudjonsson, The Psychology of Interrogations and Confessions: A Handbook (2003); N.E.S. Goldstein et al., 'Juvenile Offenders' Miranda Rights Comprehension and Self-Reported Likelihood of Offering False Confessions', 10 Assessment 359 (2003); S.A. Drizin and R.A. Leo, 'The Problem of False Confessions in the Post-DNA World', 82 North Carolina Law Review 891, at 1005 (2004); J.R. Meyer and D.N. Reppucci, ‘Police Practices and Perceptions Regarding Juvenile Interrogation and Interrogative Suggestibility', 25 Behavioral Sciences \& the Law 757, at 764 (2007); as referred to in B.C. Feld (2012), above n. 78, at 56-58.

96. F.J. Billings et al., 'Can Reinforcement Induce Children to Falsely Incriminate Themselves?', 31 Law and Human Behavior 125 (1997); as referred to in B.C. Feld (2012), above n. 78, at 56. 
does not mean, though, that juveniles are not able to participate at all and that they should be denied the right to have a say in the way they participate. Yet, in order to participate effectively in the context of police interrogations, juveniles need more than just sufficient information about their rights and the procedures. Juveniles also need special guidance and support in their decision making and protection against pressure and suggestive interrogation techniques. Mandatory access to a legal representative can be an important asset in this regard.

\section{Juveniles' Right to Counsel in the Dutch Juvenile Justice System}

In the previous paragraphs, we have scrutinised the underlying rationale and the significance of a youthspecific approach to the legal position of juveniles at the stage of police interrogations both from a children's rights and a developmental psychological perspective. A juvenile's right to (legal) counsel at the stage of police interrogations finds its justification in the notions of 'protection' and 'effective participation'. Developmental psychological research confirms and concretises the particularly vulnerable position of juveniles during police interrogations - and, thus, the need for special measures of protection - and indicates that particular safeguards are required to ensure a juvenile's effective participation.

What are the implications of these insights for a juvenile's right to (legal) counsel at the stage of police interrogations and for the pending Dutch draft bills in particular? Three core issues regarding the right to counsel will be addressed in the context of the Dutch juvenile justice system: the possibility of waiver, the role of the lawyer and the presence of a 'person of trust' during police interrogations.

\subsection{Possibility of Waiver}

The 2014 Draft Bill on implementing EU Directive (2013/48/EU) proposes that every minor from 12 until 17 years of age who is suspected of committing an offence is entitled to consultation with a lawyer prior to the first police interrogation, without the possibility of maiver. This approach is at odds with the case law of the ECtHR, in which the possibility of waiving a juvenile's right to counsel is explicitly recognised; ${ }^{97}$ a position that is also supported by various Dutch courts and has not been contested by the UN Committee on the Rights of the Child. Developmental psychological insights indicate, however, that juveniles 15 years of age and younger as well as 16- and 17-year-olds with a low IQ (below 85) often have trouble understanding their fair trial rights in the context of police interrogations.

97. Panovits v. Cyprus, ECHR (2008) No. 4268/04, para. 68
Although most 16- and 17-year-olds are considered to be cognitively able to understand their rights, they too lack 'mature decision-making competence'. Providing juveniles, including 16- and 17-year-olds, with the possibility of waiving their right to legal counsel therefore seems inappropriate. This is particularly true because developmental psychological research points out that juveniles are in need of special protection, assistance and guidance at the stage of police interrogations to prevent them from coerced or unintended selfincrimination, but also to enable them to participate effectively and in accordance with their capacities. Prior consultation with a lawyer and (legal) assistance during interrogation therefore seems a crucial prerequisite for safeguarding a juvenile's right to a fair trial.

From this perspective, the approach of the Dutch legislator not to grant arrested juvenile suspects the right to waive their right to consult a lawyer prior to the first police interrogation appears to be defendable. However, some have argued that mandatory consultation of legal counsel might de facto increase the risk that juvenile suspects will be deprived of their liberty unnecessarily as it may be complicated or even impossible to always have a lawyer present within a few hours. In the case of minor offences in particular, the consequences may be disproportionate. ${ }^{98} \mathrm{We}$ consider this a practical issue, which calls for an adequate practical solution. Yet, this practical issue ultimately touches upon a more fundamental tension between a juvenile's right to a fair trial (Article 40(2) of the CRC), which calls for (mandatory) legal consultation, and his right to personal liberty, which demands that deprivation of liberty is used only as a measure of last resort and for the shortest appropriate period of time (Article 37(b) of the CRC).

A practical solution to uplift this tension in cases in which there is no lawyer available on short notice could be to consider postponing the police interrogation for a few hours (e.g. with a maximum of 12 hours) while allowing the arrested juvenile to await his interrogation at home. Particularly in cases with no serious risk of collusion or absconding, there will not always be a need to deprive an arrested juvenile of his liberty in the period between the arrest and the first police interrogation. ${ }^{99}$ This practical solution grants a juvenile's (mandatory) consultation of a lawyer prior to the first police interrogation, while also respecting the children's rights notion of deprivation of liberty as a last resort. It does, however, require specialised police staff, who are sufficiently trained in applying this 'last resort' principle in their decisions concerning arrested juveniles. ${ }^{100}$

98. W.J. Verhoeven and L. Stevens, Rechtsbijstand bij politieverhoor. Evaluatie van de Aanwijzing rechtsbijstand politieverhoor in AmsterdamAmstelland, Groningen, Haaglanden, Limburg-Zuid, Midden- en WestBrabant en Utrecht (2013), at 314.

99. If an arrested juvenile is released until the first police interrogation, it is important that he remains entitled to be regarded as an 'arrested suspect' for the purpose of falling within the scope of the Salduz case law.

100. Cf. General Comment No. 10, Children's rights in juvenile justice, UN Doc. CRC/C/GC/10, para. 90. 
In cases of severe offences or when there is a serious risk of collusion or absconding, the police will probably not consider the release of an arrested juvenile prior to the first interrogation appropriate. In these cases it is of utmost importance that the period between the arrest and the first police interrogation is as short as possible. This does not, however, justify abandoning a juvenile's (mandatory) consultation of a lawyer prior to the interrogation, if no lawyer is available on short notice. In cases of severe offences, the stakes are high for an accused juvenile, which makes a fair trial paramount. As we have seen, (mandatory) legal counsel at the stage of police interrogations seems of vital importance for a fair trial, particularly when juveniles are concerned (see para. 5). A practical solution in these cases could be to consider the use of more innovative methods of legal consultation (i.e. via audiovisual means) if lawyers are not directly available at the police station.

\subsection{Role of the Lawyer}

The juvenile's need for special protection, assistance and guidance has important implications for the role of the defence lawyer at the stage of the police interrogations. ${ }^{101}$ It is the lawyer's responsibility to provide for adequate protection against (potential) fair trial violations and to facilitate the juvenile's effective participation. His responsibility to enable the juvenile's effective participation starts at the consultation prior to the first interrogation. During this meeting, he must adequately inform the juvenile about his rights and the procedure and empower the juvenile to express his own views about his case. This implies the lawyer's responsibility to ensure that the juvenile can exercise his right to be heard in accordance with Article 12 of the CRC. ${ }^{102}$ Together, the lawyer and the juvenile can determine the 'defence strategy'. Subsequently, the lawyer should safeguard the necessary conditions for effective participation of the juvenile during the police interrogations. The lawyer must make sure that the juvenile understands what is said during the interrogation and intervene in case he thinks the juvenile does not. In addition, he must be particularly intent on preventing the juvenile from being subjected to suggestive interrogation techniques and long-lasting interrogations, since this might badly influence the decision-making capacities of the juvenile. Moreover, sufficient protection of the juvenile suspect against compulsory self-incrimination or other fair trial violations during police interrogations require the lawyer to closely monitor the interrogation and actively intervene in case the rights of the juvenile are violated.

101. See also E. Buss, 'The role of Lawyers in Promoting Juveniles' Competence as Defendants', in T. Grisso and R.G. Schwartz (eds.), Youth on Trial. Developmental Perspectives on Juvenile Justice (2000) 243.

102. Note Art. 503 of the CCP, which stipulates that the lawyer of a juvenile younger than sixteen years can exercise the procedural rights of the juvenile independently. It is hard to reconcile this provision with the international children's rights frame and the responsibility of the lawyer as the child's representative; see also T. Liefaard, S.E. Rap \& I. Weijers, 'De positie van de jeugdige verdachte in het strafproces', 8-4 Strafblad 283 (2010).
Some have argued that, in practice, lawyers too often recommend their juvenile clients to make use of their right to remain silent, even in minor cases in which the guilt of the juvenile is claimed to be rather obvious. This approach could prevent the use of diversion mechanisms at the discretion of the police (such as the Dutch diversion programme ' $H A L T$ '), which - in the Dutch system - requires the juvenile's approval. ${ }^{103}$ According to some, this undermines the pedagogical character of juvenile justice. ${ }^{104}$ Although we consider the assumption that, in practice, lawyers too often recommend their juvenile clients to make use of their right to remain silent primarily a practical issue, it could essentially boil down to a more fundamental tension between the right to a fair trial (cf. Article 40(2) CRC) and the pedagogical interests of juvenile justice (cf. Article 40(1) CRC).

Yet, it gives no reason to question the added value of a juvenile's compulsory consultation of a lawyer. In fact, the lawyer has an important role in sufficiently informing the juvenile about the consequences of different 'defence strategies', including the consequences of making use of the right to remain silent in less serious cases, which prevent the use of diversion programs, such as $H A L T$. After all, developmental psychological research indicates that juveniles are generally not capable of understanding and overseeing these consequences without professional assistance (see para. 5). When advising the juvenile about a defence strategy during the consultation, the lawyer has the complex but important task to adhere to the interests of a fair trial (e.g. the right to remain silent) and the interests of a fast and pedagogically effective intervention (e.g. through diversion) while taking into account the best interests of the juvenile (cf. Article 3(1) of the CRC). This underscores the importance of (investing in) specialised juvenile lawyers who are fully aware of the impact of a chosen defence strategy. ${ }^{105}$

\subsection{Presence of a 'Person of 'Trust' during Interrogations}

In the 2014 Draft Bill on implementing EU Directive (2013/48/EU), the Dutch legislator explicitly chose to implement the juvenile's right to legal counsel rather than other forms of representation at the stage of police interrogations. In the Explanatory Memorandum the legislator explains that juveniles and their parents or guardians do not always have the same interests, which makes it problematic to categorical qualify parents and

103. R. Quint, 'Mogelijke onwenselijke gevolgen van de consultatie- en verhoorbijstand voor 'Haltjongeren': Een perspectief vanuit Halt', 82 Tijdschrift voor Familie- en Jeugdrecht 216 (2010); R. Quint, 'Salduzrechtspraak risico voor Halt-jongeren', 86 Nederlands Juristenblad 677 (2011). See also W.J. Verhoeven and L. Stevens, Rechtsbijstand bij politieverhoor. Evaluatie van de Aanwijzing rechtsbijstand politieverhoor in Amsterdam-Amstelland, Groningen, Haaglanden, LimburgZuid, Midden- en West-Brabant en Utrecht (2013), at 314; J.A.C. Bartels, 'De rechtspositie van het verdachte kind tijdens het politieverhoor', in C. Mak et al. (eds.), Rechten van het kind en waardigheid (2013) 291, at $298 \mathrm{ff}$.

104. Ibid

105. Ibid.See also General Comment No. 10, Children's rights in juvenile justice, UN Doc. CRC/C/GC/10, para. 90. 
guardians as appropriate representatives during police interrogations.

The decision to favour legal assistance over other assistance can be defended, also in light of the recommendations of the UN Committee on the Rights of the Child, which strongly affirm the need for legal expertise in this particular phase of the criminal justice process, even though Article 40(2) of the CRC leaves room for other forms of assistance. However, the reasoning of the legislator with regard to the role of parents is not very convincing. Parental support should not be considered the only way of granting 'other appropriate assistance', and one could argue that parental support should be an additional form of assistance (e.g. emotional) to address the particularly vulnerable position of juveniles during police interrogation. ${ }^{106}$ Parental involvement should, however, always be considered in light of the juvenile's best interests, which may require that the parents will not be allowed to be present. In this regard, one should also be aware that in some cases the presence of parents during police interrogations could have a negative impact on the juvenile's effective participation, for example, because of feelings of shame or fear. ${ }^{107}$ For this reason, juveniles should always have the possibility to waive their right to have one of their parents present during interrogation. This also implies that parents or guardians themselves should not have an independent right to be present during the interrogations of their child.

\section{Concluding Remarks}

The right to counsel of juveniles at the stage of police interrogations has gained significant attention since the Salduz ruling of the European Court on Human Rights in 2008. The legislative and policy developments that have taken place since then reveal a shared desire to accommodate the legal position of juveniles in this particularly complex phase of the criminal justice proceedings. We have tried to contribute to this development by addressing the justification for and the particularities of a youth-specific approach to the right to counsel from a multidisciplinary perspective. We hope that it can assist both the European and Dutch legislator on their way to awarding juveniles in conflict with the law a fair and youth-specific treatment.

106. The UN Committee on the Rights of the Child seems to prescribe such a cumulative approach to the right to have a lawyer and another appropriate representative (e.g. parents or guardians) present during police interrogations. See General Comment No. 10, Children's rights in juvenile justice, UN Doc. CRC/C/GC/10, para. 53. See also the commentary to Rule 15 of the Beijing Rules (see para. 4.2 above). The Dutch Supreme Court, however, adopted an alternative approach: 'assistance by a lawyer or another person of trust'. See Dutch Supreme Court, 30 June 2009, ECLI:NL:HR:2009:BH3081, para. 2.6.

107. I. Weijers, M. Bruning \& G. de Jonge, 'Ouders dwingen tot bijwonen jeugdstrafzitting is slecht idee', 6 Tijdschrift voor Familie- en Jeugdrecht 132 (2005). 